\title{
STRES KERJA, KOMITMEN ORGANISASIONAL DAN IKLIM ORGANISASI TERHADAP KEPUASAN KERJA KARYAWAN
}

\author{
Edi Siregar \\ Program Studi Manajemen Universitas Satya Negara Indonesia \\ edisiregarusni@gmail.com
}

\begin{abstract}
This research aims to know the influence of job stress, organizational commitment and organization climate has an effect to job satisfaction of employee in the office PT. Agrindo Prima Lestari. The sampling technique of this research is using census sampling, where the sampling is the all population of employees in PT. Agrindo Prima Lestari. Statistical analysis method in this research used the multiple linear regressions with the help of SPSS 22 software. Based on the result of the analysis conclude that 1) job stress has no effect to job satisfaction, 2) organizational commitment has significant effect to job satisfaction, 3) organization climate has significant effect on job satisfaction 4) job stress, organizational commitment and organization climate is jointly significant effect on employee job satisfaction.
\end{abstract}

Keyword: Job Stress, Organizational Commitment, Organization Climate, Job Satisfaction.

\section{PENDAHULUAN}

Sumber daya manusia adalah faktor sentral dalam suatu organisasi maka diperlukan upaya-upaya secara terus menerus untuk memberikan kepuasan kerja kepada para karyawan. Kepuasan kerja dirasakan karyawan setelah karyawan tersebut membandingkan antara harapan dengan hasil kerja yang diperoleh, dengan kata lain kepuasan kerja merupakan suatu tanggapan emosional seseorang terhadap situasi dan kondisi kerja.

Dari hasil wawancara yang telah dilakukan pada PT. Agrindo Prima Lestari salah satunya dengan Ibu Dian Antini sebagai kepala Human Resources Development (HRD) yaitu berupa karyawan yang merasakan puas selama bekerja. Hal ini disebabkan oleh rasa memiliki suatu kelompok atau organisasi dalam diri karyawan sangat tinggi dengan kata lain komitmen organisasional yang dimiliki oleh karyawan PT. Agrindo Prima Lestari tinggi. Komitmen organisasional PT. Agrindo Prima Lestari dapat dilihat dari intensitas karyawan yang keluar dari perusahaan relatif kecil/rendah. 
Tabel 1

Data Jumlah Karyawan PT. Agrindo Prima Lestari

\begin{tabular}{|c|c|c|c|}
\hline \multicolumn{5}{|c|}{ JUMLAH KARYAWAN PT. AGRINDO PRIMA LESTARI } \\
PERIODE 2012 - 2016 \\
\hline TAHUN & $\begin{array}{c}\text { JUMLAH KARYAWAN } \\
\text { AKHIR TAHUN }\end{array}$ & $\begin{array}{c}\text { KARYAWAN } \\
\text { KELUAR }\end{array}$ & KARYAWAN MASUK \\
\hline 2012 & 54 & 0 & 54 \\
\hline 2013 & 53 & 1 & 0 \\
\hline 2014 & 53 & 1 & 1 \\
\hline 2015 & 55 & 0 & 2 \\
\hline 2016 & 57 & 0 & 2 \\
\hline TOTAL & $\mathbf{5 7}$ & $\mathbf{2}$ & $\mathbf{5 9}$ \\
\hline
\end{tabular}

Kondisi tersebut karena iklim organisasi PT. Agrindo Prima Lestari yang terbuka, ditandai dengan kualitas kepemimpinan yang terbuka dan objektif serta memotivasi para karyawan. Untuk memperkuat kekeluargaan dan untuk menghilangkan rasa bosan para karyawan, setiap tahun PT. Agrindo Prima Lestari mengadakan acara family gathering. Berawal dari fenomena tersebut, penulis menetapkan judul tersebut di atas.Dengan empat rumusan masalah yang ditetapkan maka ada empat tujuan penelitian, yaitu: 1) Untuk mengetahui pengaruh Stres Kerja $\left(\mathrm{X}_{1}\right)$ terhadap Kepuasan Kerja (Y) Karyawan. 2) Untuk mengetahui pengaruh Komitmen Organisasional $\left(\mathrm{X}_{2}\right)$ terhadap Kepuasan Kerja (Y) Karyawan. 3) Untuk mengetahui pengaruh Iklim Organisasi $\left(\mathrm{X}_{3}\right)$ terhadap Kepuasan Kerja (Y) Karyawan. 4) Untuk mengetahui pengaruh Stres Kerja $\left(\mathrm{X}_{1}\right)$, Komitmen Organisasional $\left(\mathrm{X}_{2}\right)$ dan Iklim Organisasi $\left(\mathrm{X}_{3}\right)$ secara simultan terhadap Kepuasan Kerja $(\mathrm{Y})$ Karyawan pada PT. Agrindo Prima Lestari.

\section{LANDASAN TEORI DAN KERANGKA BERPIKIR}

Manajemen sumber daya manusia didefinisikan sebagai suatu pengelolaan dan pendayagunaan sumber daya yang ada pada individu (karyawan). Pengelolaan dan pendayagunaan tersebut dikembangkan secara maksimal di dalam dunia kerja untuk mencapai tujuan organisasi dan pengembangan individu pegawai (Mangkunegara, 2016:2).

Kepuasan kerja merupakan sikap positif terhadap pekerjaan (Daft, 2013:286). Secara umum, karyawan mengalami sikap ini ketika pekerjaan mereka sesuai dengan kebutuhan dan kepentingan karyawan, ketika kondisi kerja dan penghargaan memuaskan, ketika menyukai rekan kerja dan ketika karyawan mempunyai hubungan positif dengan supervisor. Adapun dimensi kepuasan kerja menurut Job Descriptive Index (dalam Wibowo, 2016:140) sebagai berikut:
a. The work itself (Pekerjaan Itu Sendiri)
b. Quality of supervision (Kualitas Pengawasan)
c. Relationship with co-workers (Hubungan Antar Rekan Kerja)
d. Promotion opportunities (Kesempatan Promosi)
e. Pay (Bayaran) 
Variabel bebas pertama dalam penelitian ini adalah Stres Kerja $\left(\mathrm{X}_{1}\right)$. Robbins dan Judge (2015:429) berpendapat bahwa stres kerja merupakan suatu proses psikologis yang tidak menyenangkan yang terjadi sebagai tanggapan terhadap tekanan lingkungan. Dimana dimensi stres kerja menurut Robbins dan Judge (2013:180), yaitu:

a. Kondisi Pekerjaan

1) Lingkungan Kerja Fisik

2) Pekerjaan melebihi kapasitas (Overload)

3) Pekerjaan sudah tidak lagi menarik (Deprivational)

b. Konflik Peran

c. Pengembangan Karir

d. Struktur Organisasi

Komitmen Organisasional $\left(\mathrm{X}_{2}\right)$ merupakan varibel bebas kedua yang diteliti. Greenberg dan Baron (dalam Wibowo, 2016:187) berpendapat lain bahwa komitmen organisasional merupakan suatu tingkatan di mana individu mengidentifikasi dan terlibat dengan organisasinya atau tidak ingin meninggalkannya. Berikut merupakan dimensi komitmen organisasional menurut Luthans (2012:148), yaitu:

\section{a. Affective Commitment \\ b. Continuance Commitment \\ c. Normative Commitment}

Variabel bebas pertama dalam penelitian ini adalah Iklim Organisasi $\left(\mathrm{X}_{3}\right)$. Menurut Robbins dan Judge (2015:359) iklim organisasi merupakan persepsi yang tersebar yang dimiliki oleh para anggota organisasi mengenai organisasi dan lingkungan kerja mereka. Adapun dimensi iklim organisasi menurut Litwin dan Stringer (dalam Kusdi, 2012:80) menyebutkan terdapat 5 (lima) dimensi iklim organisasi, dimensi tersebut yaitu:
a. Tanggung Jawab
b. Identitas
c. Kehangatan
d. Dukungan
e. Konflik

Berdasarkan latar belakang, rumusan masalah, tujuan dan landasan teori di atas maka kerangka penelitian yang peneliti gambarkan sebagai berikut ini: 


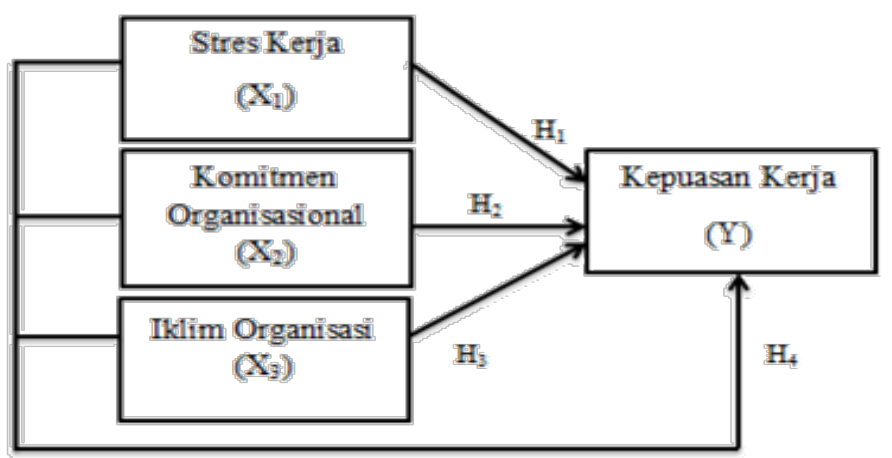

Kerangka berpikir

Sumber di olah penulis

\section{METODOLOGI PENELITIAN}

Penelitian ini dilakukan pada bulan Maret - bulan Juni tahun 2017 di PT. Agrindo Prima Lestari yang berada di Jalan Pantai Indah Selatan Komplek Sentra Industri Terpadu, Pantai Indah Kapuk Tahap III Blok E No. 27 Jakarta Utara. Desain penelitian ini menggunakan desain penelitian kausal yaitu penelitian untuk mengetahui pengaruh antara satu atau lebih variabel bebas (independent variable) terhadap variabel terikat (dependent variable). Variabel Terikat (Dependent Variable). Dalam penelitian ini variabel terikat (Y) yaitu Kepuasan Kerja. Variabel Bebas (Independent Variable). Dalam penelitian ini variabel bebas (X), yaitu: Stres Kerja $\left(\mathrm{X}_{1}\right)$, Komitmen Organisasional $\left(\mathrm{X}_{2}\right)$ dan Iklim Organisasi $\left(\mathrm{X}_{3}\right)$.

Untuk mendapatkan data-data yang dibutuhkan, maka metode pengumpulan data yang digunakan yaitu dengan riset lapangan menggunakan metode wawancara dan pemberian kuesioner. Dalam penelitian ini, terdapat jumlah populasi sebanyak 57 karyawan pada PT. Agrindo Prima Lestari. Sampel yang digunakan dalam penelitian ini adalah seluruh karyawan PT. Agrindo Prima Lestari. Karena populasi penelitian ini dibawah 100 orang, maka peneliti menggunakan teknik sensus yaitu jumlah sampel sama dengan jumlah populasi sebanyak 57 karyawan.

\section{HASIL ANALISIS DAN PEMBAHASAN}

Analisis ini bertujuan untuk mengetahui ada atau tidak hubungan antara variabel Stres Kerja $\left(\mathrm{X}_{1}\right)$, Komitmen Organisasional $\left(\mathrm{X}_{2}\right)$, Iklim Organisasi $\left(\mathrm{X}_{3}\right)$ dan Kepuasan Kerja $(\mathrm{Y})$. Berikut ini merupakan penghitungan analisis regresi linear berganda yang peneliti dapatkan. 
Tabel 2

Analisis Regresi Linear Berganda

Coefficients $^{\mathrm{a}}$

\begin{tabular}{|c|l|c|c|c|c|c|}
\hline \multicolumn{2}{|c|}{ Model } & \multicolumn{2}{|c|}{$\begin{array}{c}\text { Unstandardized } \\
\text { Coefficients }\end{array}$} & $\begin{array}{c}\text { Standardized } \\
\text { Coefficients }\end{array}$ & \multirow{2}{*}{ T } & \multirow{2}{*}{ Sig. } \\
\cline { 2 - 5 } & B & $\begin{array}{c}\text { Std. } \\
\text { Error }\end{array}$ & Beta & & \\
\hline \multirow{2}{*}{1} & (Constant) & 13.958 & 7.008 & & 1.992 & .052 \\
\cline { 2 - 6 } & Stres Kerja & .043 & .084 & .055 & .508 & .614 \\
\cline { 2 - 5 } & $\begin{array}{l}\text { Komitmen } \\
\text { Organisasional }\end{array}$ & .233 & .085 & .295 & 2.734 & .008 \\
\cline { 2 - 5 } & $\begin{array}{l}\text { Iklim } \\
\text { Organisasi }\end{array}$ & .329 & .070 & .512 & 4.732 & .000 \\
\hline
\end{tabular}

Persamaan regresi dari output SPSS di atas adalah sebagai berikut:

$$
Y=13,958+0,043 X_{1}+0,233 X_{2}+0,329 X_{3}+e
$$

Berdasarkan persamaan regresi di atas maka dapat disimpulkan bahwa nilai konstanta sebesar 13,958 yang berarti jika variabel Stres Kerja $\left(\mathrm{X}_{1}\right)$, Komitmen Organisasional $\left(\mathrm{X}_{2}\right)$ dan Iklim Organisasi $\left(\mathrm{X}_{3}\right)$ bernilai 0 maka Kepuasan Kerja (Y) bernilai 13,958. Koefisien regresi variabel Stres Kerja $\left(\mathrm{X}_{1}\right)$ sebesar 0,043: artinya jika variabel independen lain bernilai tetap dan stres kerja mengalami kenaikan 1 tingkat, maka kepuasan kerja (Y) akan mengalami penurunan 0,043. Koefisien regresi variabel Komitmen Organisasional $\left(\mathrm{X}_{2}\right)$ sebesar 0,233: artinya jika variabel independen lain bernilai tetap dan komitmen organisasional mengalami kenaikan 1 tingkat, maka kepuasan kerja (Y) akan mengalami penurunan 0,233. Koefisien regresi variabel Iklim Organisasi $\left(\mathrm{X}_{3}\right)$ sebesar 0,329: artinya jika variabel independen lain bernilai tetap dan iklim organisasi mengalami kenaikan 1 tingkat, maka kepuasan kerja (Y) akan mengalami penurunan 0,329 .

Uji t digunakan untuk mengetahui tingkat signifikansi dari pengaruh variabel independen terhadap variabel dependen secara parsial.

Tabel 3

Hasil Uji t (Uji Parsial)

Coefficients ${ }^{\mathrm{a}}$

\begin{tabular}{|c|l|c|c|c|c|c|}
\hline \multicolumn{2}{|c|}{ Model } & \multicolumn{2}{|c|}{$\begin{array}{c}\text { Unstandardized } \\
\text { Coefficients }\end{array}$} & $\begin{array}{c}\text { Standardized } \\
\text { Coefficients }\end{array}$ & \multirow{2}{*}{$\mathrm{t}$} & \multirow{2}{*}{ Sig. } \\
\cline { 3 - 7 } & B & $\begin{array}{c}\text { Std. } \\
\text { Error }\end{array}$ & Beta & & \\
\hline \multirow{2}{*}{1} & (Constant) & 13.958 & 7.008 & & 1.992 & .052 \\
\cline { 2 - 6 } & Stres Kerja & .043 & .084 & .055 & .508 & .614 \\
\cline { 2 - 6 } & $\begin{array}{l}\text { Komitmen } \\
\text { Organisasional }\end{array}$ & .233 & .085 & .295 & 2.734 & .008 \\
\cline { 2 - 6 } & Iklim Organisasi & .329 & .070 & .512 & 4.732 & .000 \\
\hline
\end{tabular}


Variabel Stres Kerja $\left(\mathrm{X}_{1}\right)$ mempunyai nilai $\mathrm{t}_{\text {hitung }}$ sebesar 0,508 dan $\mathrm{t}_{\text {tabel }}$ sebesar 2,005 dengan nilai signifikansi sebesar 0,610 >0,05 sehingga Ho diterima, berarti tidak terdapat pengaruh signifikan variabel Stres Kerja $\left(\mathrm{X}_{1}\right)$ terhadap Kepuasan Kerja (Y). Variabel Komitmen Organisasional $\left(\mathrm{X}_{2}\right)$ mempunyai nilai $t_{\text {hitung }}$ sebesar 2,734 dan nilai $t_{\text {tabel }}$ 2,005 dengan nilai signifikasi sebesar 0,008 $<0,05$ sehingga Ha diterima, berarti terdapat pengaruh signifikan variabel Komitmen Organisasional $\left(\mathrm{X}_{2}\right)$ terhadap Kepuasan Kerja (Y). Variabel Iklim Organisasi $\left(\mathrm{X}_{3}\right)$ mempunyai nilai $\mathrm{t}_{\text {hitung }}$ sebesar 4,732 dan nilai $t_{\text {tabel }}$ sebesar 2,005 dengan nilai signifikansi sebesar $0,000<0,05$ sehingga Ha diterima, berarti terdapat pengaruh signifikan variabel Iklim Organisasi $\left(\mathrm{X}_{3}\right)$ terhadap Kepuasan Kerja $(\mathrm{Y})$.

Uji f digunakan untuk mengetahui apakah variabel-variabel independen secara (bersama-sama) berpengaruh signifikan terhadap variabel dependen.

Tabel 4

Hasil Uji f (Uji Simultan)

\begin{tabular}{|c|l|c|c|c|c|c|}
\hline \multicolumn{7}{|c|}{ ANOVA $^{\mathrm{a}}$} \\
\hline \multicolumn{2}{|c|}{ Model } & $\begin{array}{c}\text { Sum of } \\
\text { Squares }\end{array}$ & Df & $\begin{array}{c}\text { Mean } \\
\text { Square }\end{array}$ & F & Sig. \\
\hline \multirow{2}{*}{1} & Regression & 372.080 & 3 & 124.027 & 11.334 & $.000^{\mathrm{b}}$ \\
\cline { 2 - 8 } & Residual & 579.956 & 53 & 10.943 & & \\
\cline { 2 - 8 } & Total & 952.035 & 56 & & & \\
\hline
\end{tabular}

Nilai $\mathrm{f}_{\text {hitung }}$ sebesar 11,334 dan $\mathrm{f}_{\text {tabel }}$ 2,780 dengan nilai signifikansi yang diperoleh adalah 0,000 berarti lebih kecil dari tingkat signifikansi 0,05 . Karena nilai $f_{\text {hitung }}>f_{\text {tabel }}$ dan nilai sig $<$ 0,05 maka Ho ditolak. Sehingga dapat disimpulkan bahwa Stres Kerja, Komitmen Organisasional dan Iklim Organisasi secara simultan berpengaruh terhadap Kepuasan Kerja karyawan.

Koefisien determinasi digunakan untuk melihat seberapa besar variabel-variabel independen secara bersama-sama mampu memberikan penjelasan mengenai variabel dependen.

Tabel 1.4

Hasil Analisis Koefisien Determinasi

\begin{tabular}{|c|c|c|c|c|}
\hline \multicolumn{5}{|c|}{ Model Summary $^{b}$} \\
\hline Model & $\mathbf{R}$ & $\begin{array}{c}\mathbf{R} \\
\text { Square }\end{array}$ & $\begin{array}{l}\text { Adjusted R } \\
\text { Square }\end{array}$ & $\begin{array}{l}\text { Std. Error of the } \\
\text { Estimate }\end{array}$ \\
\hline 1 & $.625^{\mathrm{a}}$ & .391 & .356 & 3.3080 \\
\hline
\end{tabular}

a. Predictors: (Constant), Iklim Organisasi, Stres Kerja, Komitmen

Organisasional

b. Dependent Variable: Kepuasan Kerja

Berdasarkan hasil analisis di atas dapat dilihat bahwa nilai Adjusted $R$ Square sebesar 0,356 berarti variabel Stres Kerja, Komitmen Organisasional dan Iklim Organisasi dapat 
menjelaskan atau berkontribusi terhadap variabel Kepuasan Kerja sebesar 35,6\% sedangkan sisanya $64,4 \%$ dijelaskan oleh variabel lain yang tidak dijelaskan dalam penelitian ini.

\section{KESIMPULAN DAN SARAN}

Secara parsial variabel Stres Kerja $\left(\mathrm{X}_{1}\right)$ tidak berpengaruh terhadap Kepuasan Kerja (Y) karyawan. Sementara varibel Komitmen Organisasional $\left(\mathrm{X}_{2}\right)$ berpengaruh terhadap Kepuasan Kerja (Y) karyawan dan variabel Iklim Organisasi $\left(\mathrm{X}_{3}\right)$ berpengaruh terhadap Kepuasan Kerja (Y) karyawan. Secara simultan menunjukkan bahwa dari tiga variabel yaitu Stres Kerja $\left(\mathrm{X}_{1}\right)$, Komitmen Organisasional $\left(\mathrm{X}_{2}\right)$, dan Iklim Organisasi $\left(\mathrm{X}_{3}\right)$ berpengaruh terhadap Kepuasan Kerja (Y) karyawan PT. Agrindo Prima Lestari.

Peneliti memberikan saran sebagai berikut: Acara family gathering/outing setiap tahunnya, acara tersebut dapat menjadi sarana refreshing para karyawan atau bahkan untuk anggota keluarganya. Namun, akan lebih baik jika pimpinan juga mengenali tanda-tanda awal karyawan yang telah merasakan stres kerja agar tidak menghambat pencapaian visi dan misi perusahaan. Perusahaan harus dapat menjaga kepuasan kerja baik secara financial maupun nonfinancial sehingga karyawan mempunyai sense of belonging terhadap perusahaan. Tetap mempertahankan iklim organisasi yang dirasakan oleh para karyawan saat ini. Seperti tempat atau lingkungan kerja itu sendiri, perlakuan yang diterima oleh karyawan dari manajemen serta hubungan antar rekan kerja, hal-hal tersebut dapat mempengaruhi sikap dan perilaku karyawan terhadap perusahaan. Menjaga kepuasan kerja karyawan, baik dari segi kesempatan maju, maupun kondisi atau lingkungan kerja.

\section{DAFTAR PUSTAKA}

Agung Utomo Putro, Endang Siti Astuti dan Djamhur Hamid. 2014. Pengaruh Iklim Organisasi Terhadap Eustress dan Kepuasan Kerja Karyawan Perum Jasa Tirta I Malang Jawa Timur. Jurnal Administrasi Bisnis (JAB) Vol. 14 No. 1 September 2014.

Brian Hartono dan Roy Setiawan. 2013. Pengaruh Komitmen Organisasional Terhadap Kepuasan Kerja Karyawan Paparon's Pizza City of Tomorrow. AGORA Vol. 1 No. 1 (2013)

Daft, Richard L. 2012. Era Baru Manajemen. Buku 2. Salemba Empat: Jakarta.

Gaol, L. Jimmy, 2014. A to Z Human Capital. Grasindo: Jakarta.

I Gede Putro Wibowo, Gede Riana dan Made Surya Putra. 2015. Pengaruh Stres Kerja Terhadap Kepuasan Kerja dan Komitmen Organisasional Karyawan PT. UD Ulam Sari. E-Jurnal Ekonomi dan Bisnis Universitas Udayana 4.02 (2015). ISSN : 2337 3067.

I Gusti Ayu Yuliana Lestari Putra dan I Nyoman Sudharma. 2016. Pengaruh Iklim Organisasi dan Stres Kerja Terhadap Kepuasan Kerja Karyawan Pada Hotel Asana Agung Putra Bali. E-Jurnal Manajemen Udayana. ISSN: 2302 - 8920

Irwan Lukianto. 2014. Pengaruh Kompensasi Finansial Dan Stres Kerja Terhadap Kepuasan Kerja Karyawan PT. Semenanjung Pangeran Agung. Jurnal Ilmu Manajemen Volume 2 Nomor 1 Januari 2014.

Kusdi, 2012. Budaya Organisasi. Salemba Empat: Jakarta. 
Kreitner, Robert dan Angelo Kinicki, 2014. Perilaku Organisasi. Edisi 9, Buku 1, Salemba Empat: Jakarta.

Luthans, Fred, 2012. Perilaku Organisasi, Edisi 10. Andi: Yogyakarta.

Mangkunegara, Prabu Anwar. 2013. Manajemen Sumber Daya Manusia Perusahaan. Remaja Rosdakarya: Bandung.

Moorhead, Gregory dan Ricky W, Griffin, 2013. Perilaku Organisasi: Manajemen Sumber Daya Manusia dan Organisasi, Edisi 9, Salemba Empat: Jakarta.

Priyatno, Duwi, 2014. SPSS 22 Pengolah Data Terpraktis. Andi: Yogyakarta.

Robbins, P. Stephen dan Judge, A. Timothy, 2015. Perilaku Organisasi, Salemba Empat: Jakarta.

Ruben, D. Brent dan Stewart, P. Lea, 2014. Komunikasi dan Perilaku Manusia. Rajawali Pers: Jakarta.

Sugiyono, 2016. Metode Penelitian Kuantitatif, Kualitatif, dan R\&D. Alfabeta: Bandung.

Sutrisno, Edi, 2016. Manajemen Sumber Daya Manusia. Kencana Prenada Media: Jakarta.

Veitzhal, Rivai, 2014. Manajemen Sumber Daya Manusia Untuk Perusahaan, Rajagrafindo Persada: Jakarta.

Wibowo, 2016. Perilaku dalam Organisasi. Rajawali Pers: Jakarta.

Wiratna, Sujarweni V, 2014. Metodologi Penelitian. Pustaka Baru Press: Yogyakarta. 